\title{
Effect of water and air flow on concentric tubular solar water desalting system.
}

\begin{abstract}
This work reports an innovative design of tubular solar still with a rectangular basin for water desalination with flowing water and air over the cover. The daily distillate output of the system is increased by lowering the temperature of water flowing over it (top cover cooling arrangement). The fresh water production performance of this new still is observed in Sri Ramakrishna Mission Vidyalaya College of Arts and Science, Coimbatore $\left(11^{\circ}\right.$ North, $77^{\circ}$ East), India. The water production rate with no cooling flow was $2050 \mathrm{ml} /$ day ( $410 \mathrm{ml} /$ trough). However, with cooling air flow, production increased to $3050 \mathrm{ml} /$ day, and with cooling water flow, it further increased to $5000 \mathrm{ml} /$ day. Despite the increased cost of the water cooling system, the increased output resulted in the cost of distilled water being cut in roughly half. Diurnal variations of a few important parameters are observed during field experiments such as water temperature, cover temperature, air temperature, ambient temperature and distillate output.
\end{abstract}

Keyword: Tubular solar still; Fresh water; Distillate output 